Marquette University

e-Publications@Marquette

Finance Faculty Research and Publications

Finance, Department of

$7-1-2007$

\title{
Subprime Refinancing: Equity Extraction and Mortgage Termination
}

Anthony Pennington-Cross

Marquette University, anthony.pennington-cross@marquette.edu

Souphala Chomsisengphet

Office of the Comptroller of the Currency

Accepted version. Real Estate Economics, Vol. 35, No. 2 (Summer 2007): 233-263. DOI. (C) 2007

Wiley. Used with permission. 


\section{Subprime Refinancing: Equity Extraction and Mortgage Termination}

\section{Introduction}

Declining interest rates provided incentives for many homeowners to refinance their mortgages (rate refinancing) and significant increases in house prices enabled many of these homeowners to extract equity from their home when refinancing (cash-out refinancing). As shown in table 1, according to the 2001 Residential Finance Survey $(\mathrm{RFS})^{1}$ the majority of refinances (64 percent) were able to lower their interest rate and significant fractions (27 percent) were able extract equity. ${ }^{2}$ While equity extraction is common in the prime mortgage market, it is even more prevalent in the subprime mortgage market. ${ }^{3}$ The 2001 RFS indicates that while 64 percent of prime refinances were for a rate reduction, only 40 percent of subprime refinances included a rate reduction. In addition, while 26 percent of prime refinances extract equity 49 percent of subprime refinances extracted equity. Consistent with these survey results, larger data sets confirm that a much higher proportion of refinances take cash out in the subprime mortgage market. ${ }^{4}$ We find in this paper that more than 85 percent of fixed-rate owner-

\footnotetext{
${ }^{1}$ The 2001 RFS samples approximately 68,000 Census 2000 address records. Information in the survey includes the reason for refinancing and whether the loan is considered subprime.

${ }^{2}$ Freddie Mac reports a much higher cash-out or equity extraction rate: 53 percent of all refinances in 2001. Freddie Mac also reports large swings in cash-out rates, ranging from 88 percent in 1990 to 36 percent in 2003 over the $1985-2004$ time period.

${ }^{3}$ The mortgage market is bifurcated into the prime market and the subprime market. The prime market serves those households with a sufficiently good history of making timely credit payments and the subprime market serves households with an inconsistent or seriously delinquent history of making credit payments. As a result, borrowers in the subprime mortgage market pay a substantial premium over the prevailing prime rate and tend to be liquidity constrained.

${ }^{4}$ Freddie Mac reports that in the prime market in 2003 approximately 36 percent of refinances extracted equity from the home; in the subprime market in 2003, over 75 percent of refinances extracted equity (Chomsisengphet and Pennington-Cross 2005).While Freddie Mac may purchase a few loans of subprime quality the vast majority can presumably be considered to be of prime quality. See (www.freddiemac.com/news/finance/data.html).
} 
occupied subprime refinances extracted equity through a cash-out refinance over the 1996-2003 time period.

This paper conducts two analyses of refinanced equity extraction. First, we examine the choice of borrowers to extract wealth from housing in the high-cost (subprime) segment of the mortgage market. Second, we follow the performance of the same loans through time and compare the prepayment and default termination of cash-out refinance loans to rate refinance loans. This segment of the market is an ideal one to study because of the prevalence of credit-constrained borrowers and equity extraction. The estimation of the choice to extract equity explicitly considers the fact that equity extraction is not lending for homeownership but is better viewed as one alternative available to consumers to finance consumption. For example, as shown in table 2, the RFS indicated that the cash extracted from the home's equity is often used to make home improvements, pay or consolidate existing debts and expenses, and purchase cars. Therefore, mortgage debt is a substitute for other forms of consumer debt financing (e.g., credit cards and car loans). The utilization of such debt should therefore be sensitive to both (i) the relative costs of financing debt and (ii) traditional mortgage risk measures such as changes in interest rates, down payments, and credit scores that are used to underwrite mortgages.

After origination, cash-out refinances may perform differently from typical or non-cashout, rate refinances. In particular, since removing cash will by definition reduce the amount of equity in the loan, borrowers may be more sensitive in terms of the probability of defaulting to changes in house prices. In addition, whether through learning or through necessity those who have taken cash out in the past may be more likely to 
terminate the mortgage through prepayment in the future. This paper examines these issues in a discrete time proportional hazard model using over 80,000 subprime mortgages followed from the beginning of 1996 through the end of 2003.

In the following section, we discuss in more detail why households refinance their mortgage. Section 3 empirically assesses the decision of subprime borrowers to extract the equity from their home while refinancing. Section 4 compares the performance of the cash-out loans to the non-cash-out loans. Finally, Section 5 concludes.

\section{Rate Refinancing versus Cash-out Refinancing}

A mortgage contains a call option that gives the borrower the right to prepay the mortgage at any time. Option-pricing models show that the valuation and exercise of the option are strongly tied to interest rates and their movement through time, as well as borrower characteristics (see, e.g., Dunn and McConnel, 1981; Green and Shoven, 1986; Schwartz and Torous, 1989; Clapp, Goldberg, Harding, and LaCour-Little, 2001)). Households can reduce their monthly mortgage payments by prepaying their existing mortgages and obtain a new mortgage with lower interest rate. Furthermore, other pricing models (e.g., Follain, Scott, and Yang, 1992) value the call option by comparing the savings from refinancing and the transaction costs associated with refinancing. When the savings benefit of the interest rate reduction outweighs the transaction costs, the call option is said to be optimally "in the money" and rational homeowners will refinance.

However, even if the call option is in the money, not all borrowers are able to refinance their mortgages. Borrowers' ability to refinance can be constrained by other factors such 
unemployment, income, and/or credit quality (see, e.g., Archer, Ling and McGill, 1993;

Stanton, 1995, Green and LaCour-Little, 1997; Peristiana et al., 1997). In addition, homeowners who face depreciation in their home may have insufficient collateral and thus are unable to refinance (Caplin, Freeman and Tracy 1997; Bennet, Peach, and Peristiani, 2000; Nothaft and Chang 2004).

The amount of equity affects households' decision and ability to extract the equity (Canner, Dynan and Passmore 2002). Households, particularly those who are liquidityconstrained, cash out the equity in their home because they want to fund current and future consumption (e.g., home improvement, children's education, or even vacations) or because they are financially constrained in the face of adverse shocks (e.g., a homeowner encountering a loss of job, a large medical bill, divorce expenses, and tuition expenses of a child) (Hurst 1999, Hurst and Stafford 2003). Consistent with the theory that liquidityconstrained households are more likely to use equity from the house to smooth consumption, the RFS shows that subprime borrowers are more likely than prime borrowers to take equity out of the house through a cash-out refinance. In fact, Hurst and Stafford (2003) actually show that liquidity-constrained households use 60 percent of cashed-out equity to finance current consumption. ${ }^{5}$ Agarwal, Driscoll, and Laibson (2003) observe in their sample that some households prepay even when current market

\footnotetext{
${ }^{5}$ Benjamin and Chinloy (2005) show that consumption from housing wealth is a misleading concept. Instead, consumption is associated with an increase in the size of the overall balance sheet. For example, extracting wealth out of the house increases liabilities and cash equally, thus leaving net wealth unchanged, but the balance sheet is larger. On the other hand, evidence from the U.S. National Income and Products Accounts (NIPA), the Panel Study of Income Dynamics (PSID), and international data sources all show that the propensity to consume from housing wealth is greater than the propensity to consume from over-all wealth or wealth stored in equities such as stocks or bonds (Benjamin, Chinloy, and Jud 2004a,b, Bayoumi and Edison 2003, Case, Quigley, and Shiller 2001, and Carrol, Dynan, and Krane 2003).
} 
rates are above the existing contract rate. Younger households may also be more likely to extract equity because they are more likely to be liquidity constrained (Lehnert 2004).

\section{Empirical Model: The Decision to Extract Equity}

The prior discussion indicates that the choice to extract equity while refinancing can be impacted by various factors:

$S_{i}=f\left(B_{i}, H_{i}, C_{i}\right)$

$S$ indicates the choice to take cash out when refinancing, $i$ indexes each loan, $B$ represents borrower characteristics, $H$ represents housing and mortgage characteristics, and $\mathrm{C}$ represents the relative cost of non-mortgage alternatives to finance consumption.

Borrower Characteristics: The literature suggests that negative income shocks should increase the probability of liquidity-constrained borrowers taking cash out of the house for consumption. For example, using data from the PSID Hurst and Stafford (2004) use

the households' report of whether they experienced an unemployment spell as a proxy for a negative income shock. An unemployment spell was found to have significant and positive impact on the probability of refinancing. However, the impact on equity extraction was positive, but significant only with a p-value of 9 percent. Nothaft and Chang (2004) used the American Housing Survey and found that older households are less likely to take cash out, but are also less likely to refinance in general. In addition, Lehnert (2004), also using the PSID, finds that the marginal propensity to consume (as measured by food consumption), when house prices change is impacted by life cycle concerns. Therefore, the age of the household and local unemployment rates may impact 
households' decision to extract equity while refinancing. In addition, households with more income may have more liquid assets and may find it less necessary to extract wealth from housing.

Housing and Mortgage Characteristics: In order to extract wealth there must first be some equity in the house. However, low equity has also been shown to reduce the ability of both prime and subprime borrowers to refinance regardless of the cash-out status (Pennington-Cross 2003, Danis and Pennington-Cross 2005). Since low-equity will deter both non-cash-out and cash-out refinances, it is an empirical question whether equity extraction is deterred more than typical refinances. Nothaft and Chang (2004) find that self-reported price increases in the prior two years does increase the probability of originating a cash-out refinance. In contrast, Hurst and Stafford (2004) found no relationship between self-reported loan to value ratios and the extent of equity extraction.

For the typical refinance, the main reason to refinance is to take advantage of a decrease in interest rates and reduce the monthly payment. If equity extraction is less affected by the movement of interest rates, then we should expect the probability of households cashing out the equity to be relatively lower when interest rates are declining. However, if equity extraction also relies on lower mortgage rates to make extraction attractive, then the probability of taking cash out during a refinance may be unaffected (relative to a typical refinance). Therefore, it is an empirical question whether households' decision to extract equity is positively or negatively affected by changes in interest rates and changes in house prices. 
Relative Cost of Financing: Although not considered by the empirical literature, since the cash extracted from the house is often used to purchase other goods or to consolidate existing debt, the price or interest rate of alternative consumer lending sources should be considered. For example, many households use the cash extracted to pay down existing credit card balances or to purchase a car. Therefore, the cost of these types of consumer financing should be compared with the cost of using mortgage debt.

\section{Choice Data}

The empirical tests are conducted on subprime loans that have been securitized in the private label market. The data was leased from Loanperformance. It is loan level data from the ABS data series and includes a rich set of information describing the characteristics of the loan and the credit score of the borrower. To reduce any unobserved heterogeneity, only single-family, owner-occupied, first-lien, fixed-rate mortgage refinances are included in the sample.

Loans included in the sample were originated from January 1996 through December of 2003. Chomsisengphet and Pennington-Cross (2006) provide a detailed summary of the Loanperformance data and how it has evolved through time. In general, the coverage of the subprime market increases with time and the performance of the loans is better (e.g., lower default rates) than those reported by the Mortgage Bankers Association of America (MBAA) for subprime loans. ${ }^{6}$

\footnotetext{
${ }^{6}$ MBAA indicates that their reported subprime statistics should not be viewed as representing the market. However on many dimensions the data set used in this paper also do not reflect the subprime mortgage market as a whole. Some examples of potential selection issues include - the loan application was approved, the lender chose to securitize the loan, and the loan meets ABS criteria.
} 
Table 3 provides summary statistics for the data set and a description of each variable included in the 1999-2003 period. As noted previously, cash-out refinancing is an important source of financing for the constrained homeowner: Over 85 percent of refinances extracted equity from the home by taking cash out. In many respects, cash-out refinances are very similar to non-cash-out refinances with respect to borrower and loan characteristics. For example, the FICO scores are within five points of one another and the median zip code incomes are within 2,000 dollars. However, the cash-outs are fairly evenly spread across the years 1999 through 2003, while the no cash-outs are more heavily concentrated in 2002 and 2003.

A logit model is estimated in STATA using maximum likelihood because the dependent variable is an indicator or dummy variable. The probability of extracting wealth through a cash-out refinance can be calculated as:

$\pi_{i}\left(S_{i}=1 \mid x_{i}\right)=\left(e^{x_{i} \beta} / 1+e^{x_{i} \beta}\right)$

$x$ represents a vector of borrower characteristics $(B)$, housing and mortgage characteristics $(H)$, the relative cost mortgage debt to other forms of financing consumption $(C)$, and other exogenous factors $(O)$.

Borrower characteristics $(B)$ are measured by credit score, income, and changes in unemployment rates. Since extracting equity from a home is likely associated with a negative income or life event (divorce or other unexpected change in family structure), which should impair the ability of households to make timely debt payments, it is expected that higher credit scores should reduce the probability of taking cash out. In 
addition, while borrower age and income are unknown, we proxy by using the median age and median household income for the five-digit zip code of the house, as matched with the 2000 Census zip code tabulation area. ${ }^{7}$ It is expected that households with relatively higher income have buffers of liquid wealth and thus cash-out refinances are less likely to occur in higher income zip code areas. On the other hand, cash-out refinances are more likely to occur in the younger income zip code areas because young households may not have had time to save enough money to have much liquid wealth. In addition, changes in the metropolitan area unemployment rate are used to proxy for unemployment spells and negative income shocks, which are expected to increase the probability of households in the local area extracting equity from the house.

Housing and mortgage characteristics $(H)$ are measured by changes in house prices and interest rates. Homeowners living in locations with rising house prices, measured by the percent change in the Office of Federal Housing Enterprise Oversight (OFHEO) repeat sale house price index over the prior quarter ${ }^{8}$, are more likely to take cash out when refinancing. These measures proxy for the extent that equity is available for extraction. The change in mortgage interest rates, measured by the change in prevailing rates for 30year fixed-rate mortgages and reported in the Freddie Mac Primary Mortgage Market Survey (PMMS) over the previous month, are also included. It is an empirical question

\footnotetext{
${ }^{7}$ Zip code tabulation area (zcta) definitions are not perfect matches with actual postal zip codes. For example, the census bureau did not calculate demographic and economic information for business only zip codes. Therefore, the match of the postal zip codes in the loan level data may introduce some additional error in the estimated income and age variables due to spatial matching errors. Specification tests using county level median income and age provided similar results.

${ }^{8}$ Various time periods for the change in house prices were tested (one, five year, and ten year changes in prices). Most performed similarly to the most recent quarter change in house prices likely reflecting the persistence in nominal price appreciation over the time period studied.
} 
whether rising or falling rates should induce homeowners to take out cash when refinancing.

Cost of consumer credit $(C)$ is measured by the ratio of the interest rate on credit cards and new car loans compared to mortgage interest rates. The mortgage rate is measured by the PMMS 30-year fixed-rate interest rate. The interest rate for credit cards is measured by the commercial bank rate, and the interest rate on car loans is measured by the commercial bank rate on 48-month new car loans, both of which are reported quarterly by the Federal Reserve Board. ${ }^{9}$ It is expected that households will substitute mortgage debt for a credit card and an auto loan debt as it becomes relatively less expensive. Table 4 provides summary statistics for the cost of consumer credit variables as well as a description of the variable and the source for the data. Interest rates on credit cards are on average near two times as high as those on 30-year fixed-rate mortgages, while the interest rate on 48-month car loans is on average nearly 70 percent of 30 -year fixed rate mortgages.

Lastly, to control for other unobserved factors $(O)$ such as changes in underwriting, financial market conditions, and other unobserved factors that could affect cash-out rates, we include dummy variables for the year of origination. Table 4 shows the cash-out

\footnotetext{
${ }^{9}$ Note that the expected duration of a subprime mortgage, even 30-year fixed rate mortgages, is very short; given prevailing prepayment and default rates. For example, the MBAA reports a conditional monthly in foreclosure rate over 7 percent and a 90 plus days delinquent rate over 3 percent for subprime loans from the middle of 2001 through the middle of 2003. Danis and Pennington-Cross (2005) report a conditional monthly prepayment rate on subprime loans over 4 percent. Therefore, a four year car loan has a similar if not even shorter duration than a subprime mortgage and the interest rate ratio will act as a reasonable proxy for the relative cost of debt.
} 
loans are fairly evenly distributed from 1999 through 2003, while the no-cash-out loans are more concentrated in 2002 and 2003.

\section{Choice Results}

Table 5 presents the logit choice results and provides three different specifications. In most specifications, almost all variables are significant and meet expectations. In specification I, borrower, housing and other control variables are included. In specifications II and III the relative cost of using other forms of financing are introduced. The results in Panel A show that cash-out refinances are more likely to occur in zip code areas with relatively young households as they age. However the impact of the zip code median age is much different in location that are older. To show this affect Age-35 is interacted with NYoung, a dummy variable indicating that zip code median household age is greater than or equal to 35 years. The coefficient for the variable (Age-35)*NYoung will then show any differences in refinancing patterns in areas with older households. The sign is negative and larger in magnitude than the impact of zip code age alone. Therefore, as young locations get older the probability of extracting equity increases, however, as older locations age the probability of extracting equity decreases. Wald tests (Judge et al. 1985, p. 20-25) indicate that the sum of the two coefficients are statistically different from zero in all three specifications.

Panel B reports the marginal effect of increasing any variable by one unit. All marginal effects are reported as changes in the probability of the refinance loan taking cash out. All other variables are evaluated at their means except the year of origination, which is evaluated at 2003 . 
Cash out refinances are significantly lower in the zip code areas with relatively higher median income households. Again, this result is consistent with expectations and may reflect the ability of areas with relatively higher income households to weather adverse income shocks. The impact of an increasing unemployment rate has the expected positive sign, but is insignificant. Specification tests with various lag lengths and the level of unemployment found similar results. This may reflect the inaccurate nature of overall unemployment rates at metropolitan area levels as a proxy for individual unemployment. However, using household-specific measures of unemployment spells in the PSID, Hurst and Stafford (2004) could only find a significant relationship at the 90 percent level between unemployment and removal of equity. Lastly, credit history does not have a significant impact on the likelihood of taking cash out. However, in specification tests that did not include origination year dummies the credit score was negative and statistically significant.

Refinances in locations that have experienced increases in house prices are more likely to be the cash-out variety simply because there should be more equity to extract. However, in speciation tests that did not include dummy indicators for the year of origination the coefficient estimate was negative and significant. The probability of extracting equity increases when interest rates drop. This result is contrary to the results of Nothaft and Chang (2004), who found that while refinances in general increased when interest rates declined, the impact was much smaller for cash-out refinances. Our results may differ because cash-out subprime borrowers are more sensitive to prevailing interest rate changes than prime borrowers. For example, subprime borrowers are very constrained in their access to credit markets so that changes in prevailing rates may have larger impacts 
on the present value of future payments, especially when compared with income and wealth levels.

The impact of the year dummies are very strong and show that after controlling for borrower, housing, and mortgage characteristics, refinances are more likely to be cashout in all the years before 2003. These results reflect many unobserved factors including changes in underwriting, data reporting and quality, shocks in the financial market, market consolidation, and other factors.

\section{Consumer Financing and Substitution Effects}

Specification II and III in Table 5 examine the use of home equity as a substitute for other forms of consumer financing while refinancing. Specifically, the results indicate that the higher the relative cost of using a credit card or a car loan, proxied by the ratio of credit card and car loan interest rates to mortgage interest rates $\left(i_{c c} / i_{m}\right.$ and $\left.i_{c a r} / i_{m}\right)$, the higher the probability of households extracting equity from a home.

Specification II and III do not include any measure of the change in mortgage interest rates because they were highly correlated with the credit card and car loan interest rate ratios. As compared with specification I, coefficient estimates proved to be robust to the inclusion of credit card and car loan relative interest rates. However, the increased explanatory power associated with the cost variables is small. 


\section{Parameter Stability}

The time period from 1996 through 2003 saw many changes in the subprime mortgage market. The industry has changed from a fringe market niche dominated by smaller finance companies to an important segment of both the primary and secondary market dominated by household names such as Countrywide, Indy Mac, Ameriquest and others. The change in market structure as the subprime market has matured may be associated with different underwriting standards and, as a result, parameter estimates for loans originated in different time periods may differ.

To test for parameter stability through time, specification I in Table 5 is re-estimated separately for six different origination cohorts. Selected parameter estimates are presented in table 6 for each of the origination cohorts. Because the sample of loans is much smaller in earlier years all loans originated in the years 1996 through 1998 are grouped into one cohort. The remaining cohorts represent all loans originated during the indicated calendar year. The most consistent results are the impact of median zip code age (increasing for the young and decreasing for the not-young), and median zip code income. Not surprisingly, given the prior results, unemployment rates are never significant.

Perhaps the most intriguing pattern of results is that of credit scores. In the early years higher credit scores were associated with more equity extraction, while in 2002 and 2003 higher credit scores were associated with a lower probability of extracting credit. Again, this likely reflects changing underwriting standards and the increasing use of automated 
underwriting in the subprime mortgage market. The impact of changing house prices is both positive and negative and only significant for 2003. Since regional house prices are only a rough approximation of actual individual property equity it is not surprising that the full sample is necessary to estimate the coefficient with sufficient precision. The impact of changing interest rates is usually significant but is both positive and negative. ${ }^{10}$

\section{Termination Characteristics of Cash-out Refinance Loans}

After the loan has been originated, the borrower may continue making payment or terminate the loan through default or prepayment. Given the prevalence of cash-out refinances in general, and especially in the subprime market, the difference in the performance of these loans from that of standard refinances could impact the pricing of mortgages and the long term viability of housing equity as a source of wealth used to finance consumption.

This section follows the prepayment and default behavior of the same 87,031 subprime loans used in the equity extraction estimation. Figure 1 plots the calculated monthly conditional prepay rate ${ }^{11}$ for the cash-out and no cash-out loans. It shows that over the first 20 months of a loan's life, cash-out loans on average tend to prepay less often.

Figure 2 presents the conditional monthly default rate and also shows that cash-out loans on average tend to default less often. For both cash-out and no-cash-out loans, the default rate ramps up over the first year to a year and a half and then tends to level out

\footnotetext{
${ }^{10}$ Although not reported, the same tests were conducted on specification II and III in Table 5. The credit card results were large insignificant and the car results were largely significant and mostly positive.

${ }^{11}$ The conditional rate reports the percent of loans that terminate due to default or prepayment in the current month conditional on the loan surviving through the end of the prior month.
} 
and oscillate around a fixed rate. For cash-out loans, the default fixed rate is in the 0.3 to 0.4 percent range; and for no-cash-out loans, the default fixed rate is in the 0.4 to 0.6 percent range. These figures indicate that cash-out loans may default and prepay at different rates and respond differently to shocks that may increase or decrease the propensity to terminate through default or prepayment.

The termination of a mortgage can be viewed as an outcome of two competing risks - the risk of default and the risk of prepayment. In each time period, the borrower has the option to put the mortgage and default or call the mortgage and prepay. In empirical studies of mortgage termination in the prime market, how much it is in the money to put the mortgage is often proxied by measures of how much equity is in the home. How much it is in the money to call the mortgage is often proxied by changes in interest rates since the loan was originated. Life events, typically called trigger events, may also trigger default or prepayment of a mortgage. For example, a change in family structure through divorce, life cycle issues such as trading up or down in the market, getting a better or new job in a different city or location, death or a severe illness, and many other factors can induce a household to move and prepay or even default on the mortgage (Clapp, Goldberg, Harding, and LaCour-Little 2001, Foster and Van Order 1984, Kau, Keenan, and Kim 1994a-b, Kau and Keenan 1995, and Quercia and Stegman 1992 for an early review of the literature).

Studies focusing on the subprime mortgage market have found that subprime loans tend to respond to the same economic incentives to default and prepay, although with different intensities. For example, subprime loans are less responsive to changes in interest rates 
than prime loans, while prepaying more often when it is out of the money (rising interest rates). In addition, loans that have been delinquent over long periods of time tend to prepay instead of default and show relatively high default correlation rates in the most expensive segments of the market (Alexander et al. 2002, Cowan and Cowan 2004, Pennington-Cross 2003, and Danis and Pennington-Cross 2005).

We use a multinomial logit model to reflect the competing risk of prepayment and default. Allison $(1984,1995)$ shows that when the data is set up in discrete time as in a panel data set, the multinomial logit produces the same likelihood function as a discrete time proportional hazards model. By restricting sum of the probability of default, prepayment, and continuing to one, the multinomial model controls directly for the competing risks. The likelihood function is an extension of the bivariate logit model used in the previous section and is as follows:

$$
\begin{aligned}
& \ln L=\sum_{t} \sum_{i} \sum_{j} d_{i j t} \ln \pi\left(y_{i t}=j\right) \\
& \pi\left(y_{i t}=j\right)=e^{e^{\alpha_{i t}}} /\left(1+\sum_{k=1}^{2} e^{\alpha z_{i t}}\right) \text { for } \mathrm{j}=1,2, \\
& \pi\left(y_{i t}=j\right)=1 /\left(1+\sum_{k=1}^{2} e^{\alpha \alpha_{i t}}\right) \text { for } \mathrm{j}=0 .
\end{aligned}
$$

$d_{i j t}$ is an indicator variable equal to 1 if outcome $j$ occurs for loan $i$ at time $t$ and zero otherwise, $\alpha$ are the coefficients to be estimated, and $z$ represents the explanatory variables. 
The multinomial logit model has been used to study the performance and termination of loans (for example, Phillips and VanderHoff 2004 and Heitfield and Sabarwal 2004). However, the model does assume the independence of irrelevant alternatives, which implies that the odds ratio of a pair of outcomes is independent of any of the alternative outcomes. In addition, the panel data set up also requires that the outcome in any point in time is independent of outcomes in any previous time period. While observations are assumed to be independent between loans, multiple observations for each loan are allowed to be dependent. A robust or the Huber/White/sandwich estimator of variance is used in place of the traditional calculation. Clapp, Deng, and An (2004) provide an extensive discussion of the various benefits and costs of the various choices available for competing risk and find that the multinomial model produced conservative coefficient estimates relative to models incorporating unobserved heterogeneity.

\section{Termination Data and Empirical Specification}

Table 7 provides a description of each variable used in the panel estimation data set. This data set contains the same loans described in the previous section in table 3 , but follows each loan through time until observations are censored or the loan terminates through default or prepayment. Defaults are defined as any month where the loan is identified as in foreclosure or the real estate is owned by the investor and prepayment is defined as any loan that is paid in full and was alive in the prior time period (current or delinquent). ${ }^{12}$ On average, the monthly default rate is 0.27 percent and the monthly prepayment rate is 2.05 percent. Table 8 provides means and standard deviations for key variables broken

\footnotetext{
${ }^{12}$ While it may be common for lenders in general to report loan termination with loss mitigation as prepayment rather than default, neither the data fields nor the loan documentation provide any indication of this specific type of termination event.
} 
down by loan purpose - no-cash-out refinance and cash-out refinance. On average, the cash-out loans tend to have a slightly lower monthly default rate and almost identical prepayment rate, which is somewhat surprising because higher default rates are generally associated with higher Loan-to-Values (LTVs), both at origination and in the current month. Beyond these differences, cash-out loans look very similar to non-cash-out loans.

Prior literature on mortgage performance can help identify important proxies for trigger events, ability to pay, and the extent that it is in the money to call the mortgage and prepay or put the mortgage and default.

The baseline probabilities are estimated from the age of the loan. All other variables are then interpreted as proportional shifts up or down in the baseline probability. In order not to superimpose an arbitrary shape to the baseline a step-wise linear function is estimated using ten age categories with the reference age being loan-months with age greater than 60 months.

Trigger events are proxied by the metropolitan area unemployment rate. Locations that have higher unemployment rates are more likely to be associated with individual borrower unemployment spells. These spells can make it difficult to continue making mortgage payments. Higher unemployment rates have been associated with higher rates of default in both the prime and subprime mortgage markets. However, the impact of unemployment on prepayment can be either negative or positive. For example, using subprime loans, Quercia, Stegman, and Davis (2005) find that state unemployment rates are associated with a higher probability of default and a lower probability of prepayment. 
Using prime loans, Deng, Quigley, and Van Order (2000) find state unemployment rates to be associated with higher and lower probabilities of prepaying, depending on location. When having trouble making the monthly payments, a borrower may try to prepay a mortgage instead of defaulting, if the cost of prepaying is lower than the cost of defaulting. Defaulting on a mortgage will have a longer-lasting impact on the household's ability to borrow and the cost of borrowing in the future.

In addition, gaining employment may be more difficult because many employers conduct credit history checks prior to employment. Therefore, it may be preferable for the borrower to either sell the house and provide the proceeds to the lender (often referred to as a pre-foreclosure sale) or hand the property over to the lender in exchange for extinguishing the debt (often called a deed-in-lieu of foreclosure). In fact, lenders may also wish to avoid the costs of foreclosure and even allow short sales of property (the debt is extinguished although the sale of the property does not cover all of the remaining debt). Danis and Pennington-Cross (2005) provide evidence of pre-foreclosure sales by showing that loans that are delinquent for a long time tend to prepay at elevated rates and much more often than they enter foreclosure or default.

Credit scores show the success that the borrower has had in meeting prior financial obligations and are used by lenders to screen and price mortgages. A series of papers has shown that the borrower's credit score at origination, typically the Fair Isaac consumer credit score (or FICO score), is positively associated with prepayments and negatively associated with defaults in both the prime and subprime mortgage markets (For example, 
Alexander et al 2002, Calem and Wachter 1999, Pennington-Cross 2003, and Quercia, Stegman, and Davis 2005).

To proxy for the extent that it may be in the money to put the mortgage and go into default, the estimated current LTV $(C l t v)$ is included. To calculate $C l t v$, a measure of current house prices and the outstanding balance of the mortgage are needed in each time period. House prices are updated through time using the Office of Federal Housing Enterprise Oversight repeat sale house price index. The actual mortgage balance in each month is used instead of the amortizations schedule as most prior research has done. It may make sense for a borrower to enter default if the property is in negative equity, since this implies that the value of the mortgage is larger than the value of the home. In addition, since there are transaction costs, as well as other costs associated with defaulting, and potential benefits if the borrower waits, the option to put the mortgage is not instantaneously enacted when the Cltv is greater than 1 (negative equity). Therefore, a continuous Cltv is included in the estimation. Since the current value of the house is unobserved and estimated using a repeat sale price index , a measure of the accuracy of the updated house price is also included -- called the standard error of the OFHEO House Price Index (sehpi). Sehpi is derived from the multistage process used to estimate the repeat sales price index. It estimates the diffusion of individual price appreciation rates around the index as the last observed price becomes further in the past. The more volatile the diffusion, the more likely the individual house price may have increased or decreased substantially more than the overall index. This measure has typically been used to 
calculate the probability of negative equity. ${ }^{13}$ The specification approach in this paper is to separate out the two components (Cltv and Sehpi) and allow the coefficients to vary.

The origination LTV ( $L t v)$ is also included, but this does not proxy for the option to put the mortgage; instead it reflects the unique underwriting criteria used by subprime lenders. In particular, as discussed in detail by Chomsisengphet and Pennington-Cross (2005), borrowers with lower credit scores are required to compensate by proving larger initial down payments. This approach allows lenders to at least partially reduce credit risk associated with higher default-risk loans (lower credit scores). The ability of borrowers to provide large down payments may also provide more unobserved information about the household's balance sheet and inherent riskiness (Harrison, Noordewier, and Yavas 2004).

To proxy for the extent that it is in the money to put the mortgage and refinance, we include the change in interest rates from origination and the current month $(\Delta i)$. If interest rates increase, then refinancing will lead to higher interest rates and larger monthly payments even if the mortgage size is not increased. If interest rates have declined, it is more likely that refinancing is in the money. However, due to transaction

\footnotetext{
${ }^{13}$ Probability of negative equity $=$ pneq $\left.=\Phi(\log \mathrm{V}-\log \mathrm{M}) / \mathrm{sqrt}\left(\omega^{2}\right)\right)$, where $\Phi($.$) is the cumulative standard$ normal distribution function, $\mathrm{V}$ is the value of the property, $\mathrm{M}$ is the value of the mortgage, and $\operatorname{sqrt}\left(\omega^{2}\right)$ is the standard error of the OFHEO House Price Index. The OFHEO HPI is estimated on paired sales of owner-occupied housing. In the first stage the log price of the second sale price minus the log of the first sale is regressed on a series of dummies for each time period. The dummy equals 1 for the time period of the second sale and -1 for the time period of the first sale. In the second regression the square of the residuals are regressed on the number of time periods between transactions $(\mathrm{k}), \omega^{2}=\gamma_{0}+\gamma_{1} \mathrm{k}+\gamma_{2} \mathrm{k}^{2}$. OFHEO publishes the parameters $\gamma_{1}$ and $\gamma_{2}$, which are used to calculate the estimated $\operatorname{sqrt}\left(\omega^{2}\right)$ or the standard error of the HPI (Sehpi). See Deng, Quigley, and Van Order (2000) for an implementation of pneq in a mortgage performance model and Dreiman and Pennington-Cross (2004) for a detailed discussion of the second stage estimate of repeat sales indices.
} 
costs and variations in expected duration of residence, the put option will not be instantaneously used by borrowers when interest rates drop. Therefore, the continuous change is included in the specification.

The cost of prepaying is also impacted by the existence of any prepayment penalties. An indicator is included (Prepen) showing when any prepayment penalty is in effect. It is expected that prepayment penalties will depress prepayments. In addition, since the loan information is collected from securities, many of the loans are seasoned before being observed (left censored). To control for any selection issues, the variable season is defined as the number of months since the loan was originated when first observed in the data set. Therefore, unlike the age of the loan, season varies only in the cross-section (across loans) not over time as each loan ages.

\section{Termination Results}

Three different specifications results are presented in tables 9-12. Specification I provides the naive specification, treating both cash-outs and non-cash-outs as the same. Specification II allows the baseline to shift up or down by including a dummy variable indicating if the loans is a cash-out. Specification III tests to see if the cash-out loans have different responses to the incentives to prepay or default on the mortgage. Table 11 provides the marginal impact of increasing the non-baseline variables by one unit on the probability of default or prepayment. The baseline is evaluated in the 18 to 24 months category reflecting the average observed age. The marginal impact is expressed as a proportional increase or decrease in the probability, so that 0.11 indicates the hazard (default or prepay) rate increases 11 percent, not 11 percentage points. 
In specification I, most variables have the expected signs. Specification I and II have very similar coefficient estimates for all parameters. For example, table 11 reports identical proportional marginal effects at two decimals. However, cash-out loans on average tend to significantly default and prepay less than non-cash-out loans. For the hazards of default and prepayment, the proportional impact is 11 and 9 percent, respectively.

As shown in table 9, consistent with prior research, higher credit scores are associated with lower probabilities of default and higher probabilities of prepayment. The probability of default is also sensitive to how much it is in the money to put the mortgage and default. For example, higher $c L T V$ and Sehpi are associated with higher default probabilities. Therefore, the point estimate and the volatility of the point estimate have the anticipated impact. Less equity is also associated with a lower probability of prepayment. Again, this is consistent with prior literature and reflects the role of low and negative equity as a constraint on prepayment. The volatility of house prices is associated with a higher probability of prepayment. This result may indicate that, when individual house prices are volatile around average appreciation rates, it makes it more likely that some households will have a lot less equity than typical and thus find it harder to refinance.

$L t v$, the original LTV, has a negative coefficient indicating that loans with larger down payments tend to default less. However, this impact is misleading because at origination $C l t v$ and $L t v$ are equal, so the impact of origination is fully measured by the sum of the two coefficients, which is approximately 0 . Therefore, while the marginal impact of a 
higher $L T V$ is negative, thus reflecting stricter underwriting requirements for loans with smaller down payments, the total impact on the probability of default is zero in the first time period. Over time, $c L T V$ will diverge from $L t v$ and impact the default probability appropriately.

Subprime borrowers' decision to prepay is also sensitive to the cost of refinancing and the extent that it is in the money to refinance. In particular, loans with a prepayment penalty are less likely to prepay. In fact, prepayment penalties reduce the likelihood of prepaying by 18 percent. Borrowers' prepayment decision is also sensitive to changing interest rates. For example, a one percentage point increase in interest rates reduces the probability of prepaying by 20 percent.

The proxy for trigger events, the unemployment rate, has mixed results. Higher unemployment rates are associated with higher prepayments, but have no statistically significant impact on defaults. While these results differs from previous results found in the prime market, if unemployment leads to delinquency (a few missed payments, not foreclosure), it is consistent with Danis and Pennington-Cross (2005) who showed that delinquency in the subprime market marginally increases prepayments more than defaults.

The age dummy variables indicate that the baseline or age-related hazard of default peaks at two to three years and the hazard of prepayment peaks at one to one and a half years. In addition, more seasoned loans tend to default more often and prepay less often. This 
result would be consistent with the notion that lenders tend to allow loans with marginal characteristics, observed or unobserved, more time before securitizing them.

Specification III allows the coefficient estimates for all the non-baseline variables to be different for cash-out loans and non-cash-out loans. Wald tests indicate that all cash-out versus non-cash-out coefficients are different at the 99 percent level except for Urate in the default hazard. The fourth and fifth columns in table 11 provide the marginal proportional impacts of the variables for cash-out loans and non-cash-out loans. These marginal impacts indicate that, while the Wald tests indicate statistical differences, not all variables have economically meaningful variations. For example, the impact of increasing credit scores by 10 units leads to a 11 percent reduction in default for both cash-out loans and non-cash-out loans. However, cash-out loans tend to be more responsive to the incentives to default. In fact, the marginal impact of the option to put the mortgage (Cltv and sehpi) is almost twice as large as for cash-out loans. Therefore, subprime borrowers who already cashed out the equity in their homes tend to be more responsive to negative equity positions and can be expected to default more often when house prices decline or house prices are very volatile.

In terms of prepayment, cash-out and non-cash-out loans tend respond similarly to changes in the explanatory factors, except for the house price volatility and prepayment penalty. Cash-out loans are more sensitive to sehpi, indicating that subprime borrowers will terminate (both prepay and default) more quickly when house prices are more volatile. Furthermore, borrowers who cashed out the equity from their house respond much less to prepayment penalties than those borrowers who did not cash out the equity. 
Prepayment penalties are also associated with a large increase in the probability of default for cash-out loans but have no impact on default for non-cash-out loans. These results are consistent with Quercia, Stegman, and Davis (2005), who found that subprime loans with prepayment penalties tend to default more and prepay less. Our results augment those and find that the increase in default occurs only for the loans taking cash out.

While the prior section includes a measure of the seasoning of the loan before being securitized and reported in the data set, it may be that loans that are purchased quickly or slowly react differently to the economic incentives to default and prepay. To test for this possibility the sample is split into three sub-samples or groups -- the first group includes loans seasoned up to and including 3 months, the second group includes loans seasoned more than 3 months and up to 6 months, and the last group includes loans seasoned more than 6 months. The hazard model is re-estimated for each group separately using the appropriate baseline. ${ }^{14}$ Using specification III table 12 provides the marginal impact of the non-baseline explanatory variables for each seasoning group. The default parameters are very stable across the three groups. For example, the marginal impact of credit scores ranges from -9 to -11 percent for no cash-outs and -10 to -13 percent for cash-outs. However, there is some substantial variation. For example, more seasoned cash-out loans are less sensitive to the equity position than loans with shorter seasoning periods. In addition, in terms of prepayment loans that are seasoned over a longer period are less responsive to the incentives to refinance due to changing interest rates.

\footnotetext{
${ }^{14}$ During estimation the reference group is always the youngest available loan age, given the length of the seasoning.
} 


\section{Conclusion}

Housing equity has been credited with smoothing consumption through the 2001 recession $^{15}$ and thus helping to counteract the negative impacts of the 2000-2001 stock market decline. This paper examines the propensity of subprime households to extract equity while refinancing. Most likely, because subprime households are credit- and liquidity-constrained (do not have other available sources of more liquid wealth), equity extraction is a very important segment of the subprime market, making up over 85 percent of the observed subprime refinances over the 1996-2003 time period.

Our results show that in the subprime market, lower incomes and rising house prices increase the likelihood of extracting equity while refinancing. In addition, the Residential Finance Survey and the Survey of Consumers both indicate that the cash extracted during the refinance of an existing mortgage is often used to make general purchases, consolidate and pay off other outstanding consumer debt, or purchase a car. We find evidence from individual loan-level data that subprime borrowers are actively substituting mortgage debt for credit card debt and car loans. In particular, subprime borrowers are more likely to extract equity from their house when the prevailing relative interest rates of credit card or car loans rise. These findings indicate that, in the subprime market, despite being liquidity- and credit-constrained, borrowers do respond to the relative cost of borrowing and attempt to finance consumption in the cheapest manner possible.

\footnotetext{
15 The National Bureau of Economic research dates the contraction from March 2001 through November 2001.
} 
In addition, while cash-out loans on average tend to default and prepay less than noncash-out loans, cash-out loans are more sensitive to declining house prices than non-cashout loans. Specifically, the proportional increase in the probability of default is over 75 percent higher for cash-outs than non-cash-outs $(\Delta 7 \% / \Delta 4 \%-1)$ in response to a 10 percentage point reduction in homeowner equity (current LTV). 


\section{References}

Agarwal, S., J. Driscoll, and D. Laibson, 2004. When Should Borrowers Refinance Their Mortgages? mimeo, Harvard University.

Alexander, W., S. D. Grimshaw, G.R. McQuen and B.A. Slade. 2002. Some Loans Are More Equal then Others: Third-Party Originations and Defaults in the Subprime Mortgage Industry Real Estate Economics 30(4): 667-697.

Allison, P. D. 1995. Survival Analysis Using the SAS system: A Practical Guide. Gary, Thousand Oaks, CA: Sage Publications.

Allison, P. D. 1984. Event History Analysis: Regression for Longitudinal Event Data. Thousand Oaks, CA: Sage Publications.

Archer, W., and D. Ling, 1993. Pricing Mortgage-Backed Securities: Integrating Optimal Call and Empirical Models of Prepayment. Journal of the American Real Estate and Urban Economics Association 21(4), 373-404.

Bayoumi, T. and H. Edison. 2003. Is Wealth Increasingly Driving Consumption? De Nederlandsche Bank (DNB) Staff Reports, No 101.

Benjamin, J.D., P. Chinloy and D.G. Jud. 2004a. Real Estate Versus Financial Wealth in Consumption. Journal of Real Estate Finance and Economics 29(3): 341-54.

Benjamin, J.D., P. Chinloy and D.G. Jud. 2004b. Why Do Households Concentrate Their Wealth in Housing? Journal of Real Estate Research 26(4): 329-43.

Benjamin, J.D. and P. Chinloy. 2005. Piggybanks, Spending, and Wealth. Presented at the January Allied Social Science Association conference.

Bennet, P., R. Peach, and S. Peristiani. 2000. Implied Mortgage Refinancing Thresholds. Real Estate Economics 28(3), 405-434.

Brady, P.J., G.B. Canner and D.M. Maki. 2000. The Effects of Recent Mortgage Refinancing. Federal Reserve Bulletin 86(7): 441-50.

Canner, G.B., K. Dynan and W. Passmore. 2002. Mortgage Refinancing in 2001 and Early 2002. Federal Reserve Bulletin 88(12): 469-81.

Caplin, A., C. Freeman, and J. Tracy, 1997. Collateral Damage: Refinancing Constraints and Regional Recessions. Journal of Money, Credit, and Banking 29(4), 496-516.

Carroll, C.D., K. Dynan and S.D. Krane. 2003. Unemployment Risk and Precautionary Wealth: Evidence from Households' Balance Sheets. Review of Economics and Statistics 85(3): 586-604

Case, K.E., J.M. Quigley and R. Shiller. 2001. Comparing Wealth Effects: The Stock Market versus the Housing Market. Cowles Foundation, Yale University, Cowles Foundation Discussion Papers 1335.

Chomsisengphet, S. and A. Pennington-Cross. 2006. The Evolution of the Subprime Mortgage Market. Federal Reserve Bank of St. Louis Review, January/February 2006, 88(1), pp. 31-56. 
Clapp, J.M., Y. Deng and X. An. 2004. Alternative Models for Competing Risks of Mortgage Termination. Working Paper \#2004-1002, Los Angeles: Lusk Center for Real Estate, University of Southern California.

Cowan, A. and C. Cowan. 2004. Default Correlation: An Empirical Investigation of a Subprime Lender. Journal of Banking and Finance 28(4): 753-771.

Danis, M. and A. Pennington-Cross. 2005. A Dynamic Look at Subprime Loan Performance. The Journal of Fixed Income 15(1): 28-39.

Deng, Y., J. Quigley and R. Van Order. 2000. Mortgage Terminations, Heterogeneity and the Exercise of Mortgage Options. Econometrica 68(2): 275-307.

Dreiman, M. and A. Pennington-Cross. 2004. Alternative Methods of Increasing the Precision of the Weighted Repeat Sales House Price Indices. The Journal of Real Estate Finance and Economics 28(4): 299-318.

Dunn, K.B. and J.J. McConnell, 1981. A Comparison of Alternative Models of Pricing GNMA Mortgage-Backed Securities. Journal of Finance 36(2), 471-484.

Follain, J.R., L.O. Scott, and T. Yang, 1992. Micro foundations of a Mortgage Prepayment Function. Journal of Real Estate Finance and Economics 5(2), 197-217.

Foster, C. and R.V. Order. 1984. An Option Based Model of Mortgage Default. Housing Finance Review 3(4): 351-372.

Green, R.K. and M. LaCour-Little. 1997. Some Truths About Ostriches: Who Never Refinances their Mortgage and Why They Don't. Journal of Housing Economics 8, 233248.

Green, J., and J. Shoven, 1986. The Effects of Interest Rates on Mortgage Prepayment. Journal of Money, Credit and Banking 18(1), 41-59.

Harrison, D.M., T.G. Noordewier and A. Yavas. 2004. Do Riskier Borrowers Borrow More? Real Estate Economics 32(3): 385-411.

Heitfield, E. and T. Sabarwal. 2004. What Drives Default and prepayment on Subprime Auto loans? Journal of Real Estate Finance and Economics 29(4): 457-477.

Hurst, E. and F. Stafford. 2004. Home Is Where the Equity Is: Mortgage Refinancing and Household Consumption. Journal of Money, Credit, and Banking 36(6): 985-1014.

Hurst, E., 1999. Household Consumption and Household Type: What can we Learn from Mortgage Refinancing? Working Paper, University of Chicago.

Judge, G.G., W.E. Griffths, R.C. Hill, H. Lutkepohl and T-C. Lee. 1985. The Theory and Practice of Econometrics. $2^{\text {nd }}$ edition. New York: Wiley.

Kau, J.B. and D.C. Keenan. 1995. An Overview of the Option Theoretic Pricing in Mortgages. Journal of Housing Research 6(2): 217-244.

Kau, J.B., D.C. Keenan and T. Kim. 1994. Default Probabilities for Mortgages. Journal of Urban Economics 35(3): 378-296.

Kau, J.B., D.C. Keenan and T. Kim. 1994b. Waiting to Default: The Value of Delay. Journal of the American Real Estate and Urban Economics Association 22(3): 539-551. 
Lehnert, A. 2004. Housing, Consumption, and Credit Constraints. Board of Governors of the Federal Reserve System (U.S.), Finance and Economics Discussion Series, 2004(63).

Nothaft, F.E. and Y. Chang, 2004, "Refinance and the Accumulation of Home Equity Wealth," Freddie Mac Working Paper \#04-02 (available at www.freddiemac.com).

Pennington-Cross, A. 2003. Credit History and the Performance of Prime and Nonprime Mortgages. Journal of Real Estate Finance and Economics 27(3): 279-301.

Peristiani, S., P. Bennett, R. Peach, and J. Raiff. 1997. Credit, Equity, and Mortgage Refinancings. Federal Reserve Bank of New York Economic Policy Review, July, 83-103.

Phillips, R.A. and J.H. Vanderhoff. 2004. The Conditional Probability of Foreclosure: An Empirical Analysis of Conventional Mortgage Loan Defaults. Real Estate Economics 32(4): 571-588.

Quercia, R.G. and M.A. Stegman. 1992. Residential Mortgage Default: A Review of the Literature. Journal of Housing Research 3(2): 341-370.

Quercia, R.G., M. Stegman and W. Davis. 2005. The Impact of Predatory Loan Terms on Subprime Foreclosures: The Special Case of Prepayment Penalties and Balloon Payments. University of North Carolina Kenan-Flagler Business School, January 25.

Schwartz, E.S., and W.N. Torous, 1989. Prepayment and the Valuation of MortgageBacked Securities. Journal of Finance. 44(2), 375-392.

Stanton, R., 1995. Rational Prepayment and Valuation of Mortgage-Backed Securities. Review of Financial Studies 8(3), 677-708.

Tracy, J., H. Schneider and S. Chan. 1999. Are Stocks Over-Taking Real Estate in Household Portfolios? Current Issues in Economics and Finance, Federal Reserve Bank of New York, 5(5): available at http://www.ny.frb.org/research/current_issues. 
Table 1: Reasons to Refinance

\begin{tabular}{|c|c|c|c|c|c|c|}
\hline \multirow[t]{4}{*}{ Reason } & \multirow{2}{*}{\multicolumn{2}{|c|}{ All Loans }} & \multirow{2}{*}{\multicolumn{2}{|c|}{ Prime Loans }} & \multicolumn{2}{|c|}{ Subprime Loans } \\
\hline & & & & & & Percent of \\
\hline & \# of & of All & \# of & Prime & \# of & Subprime \\
\hline & Loans & Loans & Loans & Loans & & Loans \\
\hline $\begin{array}{l}\text { Lower interest } \\
\text { rate }\end{array}$ & 1,624 & 64.1 & 1,551 & 66.0 & 73 & 39.7 \\
\hline Increase & & & & & & \\
\hline payment period & 21 & 0.8 & 20 & 0.9 & 1 & 0.5 \\
\hline Reduce & & & & & & \\
\hline payment period & 74 & 2.9 & 67 & 2.8 & 7 & 3.8 \\
\hline due & 55 & 2.2 & 51 & 2.2 & 4 & 2.2 \\
\hline Receive cash & 694 & 27.4 & 604 & 25.7 & 90 & 48.9 \\
\hline $\begin{array}{l}\text { Other reason - } \\
\text { Specify }\end{array}$ & 67 & 26 & 58 & 25 & 9 & 49 \\
\hline Total & 2,535 & 100 & 2,351 & 100 & 184 & 100 \\
\hline
\end{tabular}

Source: Calculations from the 2001 Residential Finance Survey, home owners file.

Table 2: Detailed Reasons for Cash-out Refinance

\begin{tabular}{l|cc}
\hline Reason & \# of Loans & $\begin{array}{c}\text { Percent of } \\
\text { Cash-outs }\end{array}$ \\
\hline Start a business & 21 & 3.0 \\
Consolidate debt & 589 & 84.9 \\
Settle a divorce & 37 & 5.3 \\
Pay expenses & 93 & 13.4 \\
Pay taxes & 38 & 5.5 \\
Buy products & 37 & 5.3 \\
Invest in real estate & 89 & 12.8 \\
Improve property & 593 & 85.4 \\
Buy a vehicle & 120 & 17.3 \\
\hline
\end{tabular}

Source: Calculations from the 2001 Residential Finance Survey, home owners file. Loans may have more than one reason for taking cash out. 
Table 3: Summary Statisites of Borrower, Housing, and Mortgage Characteristics

\begin{tabular}{|c|c|c|c|c|c|}
\hline Variable & Description & $\begin{array}{l}\text { No Cas } \\
\text { Mean }\end{array}$ & $\begin{array}{l}\text {-out } \\
\text { Std. } \\
\text { Dev. }\end{array}$ & $\begin{array}{l}\text { Cash } \\
\text { Mean }\end{array}$ & $\begin{array}{l}\text { Std. } \\
\text { Dev. }\end{array}$ \\
\hline FICO & $\begin{array}{l}\text { Fair Isaac's credit score at } \\
\text { origination. Source: Loan level } \\
\text { data. }\end{array}$ & 649.17 & 72.41 & 645.68 & 66.31 \\
\hline Age & $\begin{array}{l}\text { Median age of people living the } \\
\text { five digit zip code (zip code } \\
\text { tabulation area). Source: } 2000 \\
\text { Census. }\end{array}$ & 35.18 & 4.68 & 35.05 & 4.60 \\
\hline NYoung & $\begin{array}{l}\text { Indicator of Age greater than or } \\
\text { equal to } 35 \text { years. }\end{array}$ & 0.53 & 0.50 & 0.51 & 0.50 \\
\hline NYoung*Age & $\begin{array}{l}\text { Interaction of (Age-35) and } \\
\text { NYoung. }\end{array}$ & 1.80 & 3.08 & 1.68 & 3.08 \\
\hline Income & $\begin{array}{l}\text { Median household income in the } \\
\text { five digit zip code (zip code } \\
\text { tabulation area). Source: } 2000 \\
\text { Census. }\end{array}$ & 47,277 & 16,089 & 45,193 & 14,298 \\
\hline$\Delta$ urate & $\begin{array}{l}\text { Change in the metropolitan area } \\
\text { unemployment rate in the month } \\
\text { prior to origination. Source: } \\
\text { Bureau of Labor and Statistics. }\end{array}$ & 0.01 & 0.51 & 0.02 & 0.52 \\
\hline$\Delta \mathrm{hpi}$ & $\begin{array}{l}\text { Percent change in metropolitan } \\
\text { area house prices in the quarter } \\
\text { before the loan is originated. } \\
\text { Source: Office of Federal Housing } \\
\text { Enterprise and Oversight repeat } \\
\text { sales house price index (OFHEO } \\
\text { HPI). }\end{array}$ & 1.51 & 1.19 & 1.44 & 1.15 \\
\hline$\Delta \mathrm{i}$ & $\begin{array}{l}\text { Change in mortgage interest rates } \\
\text { over the one month prior to } \\
\text { origination. Source: The } 30 \text {-year } \\
\text { fixed rate mortgage interest rate } \\
\text { reported by Freddie Mac in } \\
\text { Primary Mortgage Market Survey } \\
\text { (PMMS). }\end{array}$ & -0.07 & 0.43 & -0.06 & 0.44 \\
\hline Number of Loans & $\begin{array}{l}\text { Number of loans originated. } \\
\text { Source: Loan level data. }\end{array}$ & 12,964 & & 74,067 & \\
\hline
\end{tabular}

Fixed-rate owner-occupied loans originated from 1996 through 2003. See text for more details on the data set. 
Table 4: Summary Statistics of Cost of Consumer Credit and Year of Origination Characteristics

\begin{tabular}{|c|c|c|c|c|c|}
\hline Variable & Description & $\begin{array}{l}\text { No Cas } \\
\text { Mean }\end{array}$ & $\begin{array}{l}\text {-out } \\
\text { Std. } \\
\text { Dev. }\end{array}$ & $\begin{array}{c}\text { Cash } \\
\text { Mean }\end{array}$ & $\begin{array}{l}\text { out } \\
\text { Std. } \\
\text { Dev. }\end{array}$ \\
\hline $\mathrm{i}_{\mathrm{cc}} / \mathrm{i}_{\mathrm{m}}$ & $\begin{array}{l}\text { Ratio of the prevailing interest } \\
\text { rates for credit cards and } \\
\text { mortgages. Source: Commercial } \\
\text { bank interest rate on credit cards } \\
\text { as reported by the Federal } \\
\text { Reserve Board and PMMS. }\end{array}$ & 2.10 & 0.16 & 2.06 & 0.16 \\
\hline $\mathrm{i}_{\mathrm{car}} / \mathrm{i}_{\mathrm{m}}$ & $\begin{array}{l}\text { Ratio of the prevailing interest } \\
\text { rates for cars and mortgages. } \\
\text { Source: Commercial bank interest } \\
\text { rate on } 48 \text { month new car loans } \\
\text { and PMMS. }\end{array}$ & 0.71 & 0.19 & 0.77 & 0.20 \\
\hline yr96 & $\begin{array}{l}\text { Indicator of loan originated in } \\
\text { 1996. Source: Loan level. }\end{array}$ & 0.00 & 0.07 & 0.02 & 0.12 \\
\hline yr97 & $\begin{array}{l}\text { Indicator of loan originated in } \\
\text { 1997. Source: Loan level. }\end{array}$ & 0.04 & 0.20 & 0.05 & 0.21 \\
\hline yr98 & $\begin{array}{l}\text { Indicator of loan originated in } \\
\text { 1998. Source: Loan level. }\end{array}$ & 0.09 & 0.29 & 0.10 & 0.29 \\
\hline yr99 & $\begin{array}{l}\text { Indicator of loan originated in } \\
\text { 1999. Source: Loan level. }\end{array}$ & 0.10 & 0.30 & 0.16 & 0.37 \\
\hline yr00 & $\begin{array}{l}\text { Indicator of loan originated in } \\
2000 \text {. Source: Loan level. }\end{array}$ & 0.08 & 0.27 & 0.14 & 0.35 \\
\hline yr01 & $\begin{array}{l}\text { Indicator of loan originated in } \\
\text { 2001. Source: Loan level. }\end{array}$ & 0.12 & 0.33 & 0.19 & 0.39 \\
\hline yr02 & $\begin{array}{l}\text { Indicator of loan originated in } \\
\text { 2002. Source: Loan level. }\end{array}$ & 0.21 & 0.41 & 0.16 & 0.37 \\
\hline yr03 & $\begin{array}{l}\text { Indicator of loan originated in } \\
\text { 2003. Source: Loan level. }\end{array}$ & 0.35 & 0.48 & 0.19 & 0.39 \\
\hline
\end{tabular}


Table 5: Logit Choice Results: The Likelihood of Extracting Equity Panel A: Coefficient Estimates

\begin{tabular}{|c|c|c|c|c|c|c|c|}
\hline \multirow{2}{*}{ Variable } & & \multicolumn{2}{|c|}{ I. Base } & \multicolumn{2}{|c|}{ II. Credit Card } & \multicolumn{2}{|c|}{ III. Car } \\
\hline & & Coefficient & z-stat & Coefficient & z-stat & Coefficient & z-stat \\
\hline \multirow[t]{5}{*}{ Borrower } & FICO & 0.005 & 0.4 & 0.005 & 0.3 & 0.004 & 0.3 \\
\hline & Age & $0.135^{\star * *}$ & 3.2 & $0.134^{\star *}$ & 3.2 & $0.133^{\star * *}$ & 3.1 \\
\hline & Age*NYoung & $-0.211^{\star * \star}$ & -3.4 & $-0.211^{\star \star *}$ & -3.4 & $-0.208^{* * *}$ & -3.4 \\
\hline & Income & $-0.085^{\star * *}$ & -12.8 & $-0.085^{\star * *}$ & -12.8 & $-0.085^{\star * *}$ & -12.8 \\
\hline & $\Delta$ urate & 0.191 & 1.0 & 0.202 & 1.1 & 0.222 & 1.2 \\
\hline \multirow[t]{2}{*}{ Housing } & $\Delta$ hpi & $0.030^{* * *}$ & 3.6 & $0.030^{* * *}$ & 3.6 & $0.026^{* *}$ & 3.0 \\
\hline & $\Delta \mathrm{i}$ & $-0.060^{* *}$ & -2.3 & & & & \\
\hline \multirow{2}{*}{$\begin{array}{l}\text { Credit Card Cost } \\
\text { Car Cost }\end{array}$} & $\left(\mathrm{i}_{\mathrm{cc}} / \mathrm{i}_{\mathrm{m}}\right)$ & & & $0.161^{*}$ & 1.7 & & \\
\hline & $\left(\mathrm{i}_{\mathrm{car}} / \mathrm{i}_{\mathrm{m}}\right)$ & & & & & $0.382^{* * *}$ & 5.5 \\
\hline \multirow[t]{9}{*}{ Other } & yr96 & $1.953^{* \star *}$ & 14.1 & $1.988^{* \star *}$ & 14.1 & $1.678^{\star * *}$ & 11.4 \\
\hline & yr97 & $0.749^{\star \star \star}$ & 14.7 & $0.787^{\star \star \star}$ & 14.9 & $0.624^{* * *}$ & 11.1 \\
\hline & yr98 & $0.674^{* * *}$ & 18.4 & $0.681^{* * *}$ & 18.7 & $0.552^{* * *}$ & 12.7 \\
\hline & yr99 & $1.103^{\star \star *}$ & 30.4 & $1.117^{* * *}$ & 26.5 & $0.954^{* * *}$ & 23.1 \\
\hline & yr00 & $1.250^{\star \star \star}$ & 33.4 & $1.313^{\star \star \star}$ & 24.8 & $1.159^{* * *}$ & 28.2 \\
\hline & yr01 & $1.028^{\star \star \star}$ & 31.9 & $1.073^{\star * *}$ & 29.5 & $0.961^{* * *}$ & 27.6 \\
\hline & yr02 & $0.354^{\star \star *}$ & 12.7 & $0.403^{* * *}$ & 11.5 & $0.342^{* * *}$ & 12.4 \\
\hline & constant & $0.991^{\star * *}$ & 6.0 & $0.638^{\star *}$ & 2.3 & $0.795^{\star * *}$ & 4.7 \\
\hline & $\begin{array}{l}\text { Log of } \\
\text { Likelihood }\end{array}$ & $-35,304.1$ & & $-35,305.4$ & & $-35,291.9$ & \\
\hline
\end{tabular}

Panel B: Marginal Effects: The Change in the Probability to Extracting Equity

\begin{tabular}{|c|c|c|c|c|}
\hline \multicolumn{2}{|l|}{ Variable } & I. Base & II. Credit Card & III. Car \\
\hline \multirow[t]{5}{*}{ Borrower } & FICO & $0.1 \%$ & $0.1 \%$ & $0.1 \%$ \\
\hline & Age & $2.5 \%$ & $2.5 \%$ & $2.4 \%$ \\
\hline & Age ${ }^{\star}$ Young & $-3.9 \%$ & $-4.0 \%$ & $-3.7 \%$ \\
\hline & Income & $-1.6 \%$ & $-1.6 \%$ & $-1.5 \%$ \\
\hline & $\Delta$ urate & $3.5 \%$ & $3.8 \%$ & $4.0 \%$ \\
\hline Housing & $\begin{array}{l}\Delta \text { hpi } \\
\Delta \mathrm{i}\end{array}$ & $\begin{array}{r}0.6 \% \\
-1.1 \%\end{array}$ & $0.6 \%$ & $0.5 \%$ \\
\hline $\begin{array}{l}\text { Credit Card Cost } \\
\text { Car Cost }\end{array}$ & $\begin{array}{l}\left(\mathrm{i}_{c c} / \mathrm{i}_{\mathrm{m}}\right) \\
\left(\mathrm{i}_{\mathrm{car}} / \mathrm{i}_{\mathrm{m}}\right)\end{array}$ & & $3.0 \%$ & $6.8 \%$ \\
\hline \multirow[t]{7}{*}{ Other } & yr96 & $20.1 \%$ & $20.7 \%$ & $17.9 \%$ \\
\hline & yr97 & $11.2 \%$ & $11.9 \%$ & $9.3 \%$ \\
\hline & yr98 & $10.3 \%$ & $10.6 \%$ & $8.4 \%$ \\
\hline & yr99 & $14.8 \%$ & $15.2 \%$ & $12.8 \%$ \\
\hline & yr00 & $16.0 \%$ & $16.8 \%$ & $14.6 \%$ \\
\hline & yr01 & $14.1 \%$ & $14.8 \%$ & $12.9 \%$ \\
\hline & yr02 & $5.9 \%$ & $6.8 \%$ & $5.5 \%$ \\
\hline
\end{tabular}

The dependent variable is 1 is the refinance takes out cash and 0 otherwise. FICO is divided by 100 , income is divided by 10,000 , age is divided by 10 , and $\Delta$ urate is divided by $10 . \Delta \mathrm{i}$ is dropped from the specifications II and II because of a high rate of correlation with $\mathrm{i}_{\mathrm{cc}} / \mathrm{i}_{\mathrm{m}}$ and $\mathrm{i}_{\mathrm{car}} / \mathrm{i}_{\mathrm{m}}$. Marginal effects are reported for a one unit change in the variable and all other variables are evaluated at their means. Dummy variables are evaluated as 0 to 1 changes. 
Table 6: Parameter Stability and Origination Years

\begin{tabular}{ll|rccccc}
\hline & & \multicolumn{7}{|c}{ Year of Origination } \\
\hline Variable & Variable & $1996-98$ & 1999 & 2000 & 2001 & 2002 & 2003 \\
\hline Borrower & FICO & $0.64^{*}$ & $0.60^{*}$ & $0.52^{*}$ & 0.07 & $-0.37^{*}$ & $-0.48^{*}$ \\
& Age & 0.04 & $0.44^{*}$ & $0.34^{*}$ & 0.06 & 0.11 & 0.11 \\
& Age*NYoung & -0.06 & $-0.70^{*}$ & $-0.57^{*}$ & -0.22 & $-0.22^{*}$ & -0.05 \\
& Income & -0.03 & $-0.04^{*}$ & $-0.10^{*}$ & $-0.11^{*}$ & $-0.07^{*}$ & $-0.10^{*}$ \\
& Lurate & 0.25 & 0.02 & -0.22 & -0.57 & 0.26 & 0.10 \\
\hline Housing & $\Delta \mathrm{hpi}$ & -0.03 & 0.01 & 0.00 & 0.04 & -0.01 & $0.08^{*}$ \\
& $\Delta \mathrm{i}$ & $-0.79^{*}$ & $0.22^{*}$ & $-0.19^{*}$ & $-0.20^{*}$ & $0.30^{*}$ & $-0.16^{*}$ \\
\hline
\end{tabular}

The dependent variable is 1 is the refinance takes out cash and 0 otherwise. Each column provides the estimated coefficient using the base model specification and only loans from the origination year indicated; * indicates that the coefficient estimated is statistically significant at the 10 percent level or better. 
Table 7: Description of Termination Data Set

\begin{tabular}{|c|c|c|c|}
\hline Variable & Description & Mean & Std. Dev. \\
\hline Default & $\begin{array}{l}\text { Indicator that the loan defaulted in the } \\
\text { current month. Default is defined as a loan } \\
\text { entering foreclosure or becoming real estate } \\
\text { owned property. Source: loan level data. }\end{array}$ & 0.0027 & 0.05 \\
\hline Prepay & $\begin{array}{l}\text { Indicator that the loan prepaid in the current } \\
\text { month. Prepaid is defined as a loan being } \\
\text { paid in full whether delinquent or current in } \\
\text { the prior month. Source: loan level data. }\end{array}$ & 0.0205 & 0.14 \\
\hline Lage & $\begin{array}{l}\text { The number of months since the loan was } \\
\text { originated in each month, or loan age. }\end{array}$ & 22.2542 & 16.30 \\
\hline Fico & $\begin{array}{l}\text { Fair Isaac's consumer credit score at } \\
\text { origination divided by } 10 \text {. Source: loan level } \\
\text { data. }\end{array}$ & 64.5461 & 6.60 \\
\hline Ltv & $\begin{array}{l}\text { The loan to value ratio at origination. } \\
\text { Source: loan level data. }\end{array}$ & 91.0438 & 22.24 \\
\hline Cltv & $\begin{array}{l}\text { month. Source: House price is updated } \\
\text { using the Office of federal housing } \\
\text { Enterprise Oversight (OFHEO) repeat sales } \\
\text { house price index (HPI) for the state. The } \\
\text { loan balance in each month is observed in } \\
\text { the loan level data. }\end{array}$ & 79.3761 & 22.22 \\
\hline & $\begin{array}{l}\text { The standard error of the OFHEO HPI. This } \\
\text { measure of price uncertainty measures the } \\
\text { diffusion of individual property prices around } \\
\text { the estimated index as the time period } \\
\text { between the observed (origination) price and } \\
\text { the current price increases. Source: OFHEO }\end{array}$ & & \\
\hline Sehpi & HPI state diffusion parameters. & 7.9701 & 3.19 \\
\hline Season & $\begin{array}{l}\text { The age of the lan when first observed in } \\
\text { the data set reflecting the seasoning of the } \\
\text { loan when securitized. Source: loan level } \\
\text { data. }\end{array}$ & 5.8262 & 10.15 \\
\hline Prepen & $\begin{array}{l}\text { An indicator that the loan has a prepayment } \\
\text { penalty in effect for the current month. } \\
\text { Source: loan level data. }\end{array}$ & 0.5717 & 0.49 \\
\hline & $\begin{array}{l}\text { The change in prevailing } 30 \text {-year fixed rate } \\
\text { mortgage interest rates from the date of } \\
\text { origination to the current month. Source: } \\
\text { The Freddie Mac Primary Mortgage Market }\end{array}$ & & \\
\hline$\Delta \mathrm{l}$ & Survey. & -0.5039 & 0.87 \\
\hline Urate & $\begin{array}{l}\text { The metropolitan area unemployment rate in } \\
\text { the current month. Source: the U.S. Bureau } \\
\text { of labor and Statistics, }\end{array}$ & 4.8125 & 1.98 \\
\hline Cash-out & $\begin{array}{l}\text { Indicator that the loan was originated as a } \\
\text { refinance loan taking cash out. The } \\
\text { reference loan type is refinance loans not } \\
\text { taking any cash out. Source: loan level data. }\end{array}$ & 0.8809 & 0.32 \\
\hline & $\begin{array}{l}\text { Number of observation in the panel } \\
\text { estimation data set. Source: loan level } \\
\text { data. Same loans as included in table } 3 \text { and }\end{array}$ & & \\
\hline Observations & 4. & $1,785,480$ & \\
\hline
\end{tabular}


Table 8: Summary Statistics of the Termination Data Set: Cash-out and Non-cashout Refinances

\begin{tabular}{l|rr|rr}
\hline & \multicolumn{2}{|c|}{ No Cash-out } & \multicolumn{2}{c}{ Cash-out } \\
Variable & \multicolumn{1}{|c|}{ Mean } & Std. Dev. & Mean & Std. Dev. \\
\hline Default & 0.0036 & 0.06 & 0.0026 & 0.05 \\
Prepay & 0.0199 & 0.14 & 0.0206 & 0.14 \\
Lage & 20.1726 & 16.56 & 22.5357 & 16.24 \\
Fico & 63.6323 & 7.17 & 64.6697 & 6.51 \\
Ltv & 79.7324 & 14.23 & 92.5734 & 22.69 \\
Cltv & 71.4014 & 15.80 & 80.4545 & 22.74 \\
Sehpi & 7.4925 & 3.31 & 8.0347 & 3.17 \\
Season & 5.4380 & 10.28 & 5.8787 & 10.14 \\
Prepen & 0.5446 & 0.50 & 0.5753 & 0.49 \\
Ll & -0.4263 & 0.81 & -0.5144 & 0.87 \\
Urate & 4.8776 & 1.97 & 4.8037 & 1.98 \\
\hline Observations & 212,683 & & $1,572,797$ \\
\hline
\end{tabular}


Table 9: The Likelihood of Defaulting and Prepaying

\begin{tabular}{|c|c|c|c|c|c|}
\hline & \multicolumn{2}{|l|}{ I } & \multicolumn{2}{|l|}{ II } \\
\hline & & Coefficient & z-stat & Coefficient & z-stat \\
\hline \multicolumn{6}{|l|}{ Default } \\
\hline & Lage $<=6$ & $-0.905^{\star * *}$ & -4.1 & $-0.895^{\star * *}$ & -4.1 \\
\hline & $6<$ Lage $<=8$ & 0.163 & 0.8 & 0.174 & 0.9 \\
\hline & $8<$ Lage $<=10$ & $0.416^{* *}$ & 2.2 & $0.427^{* *}$ & 2.3 \\
\hline & $10<$ Lage $<=12$ & $0.581^{* * *}$ & 3.2 & $0.591^{\star * *}$ & 3.3 \\
\hline & $12<$ Lage $<=18$ & $0.579^{\star * *}$ & 3.5 & $0.590^{* * *}$ & 3.5 \\
\hline & $18<$ Lage $<=24$ & $0.651^{* * *}$ & 4.2 & $0.661^{* * *}$ & 4.3 \\
\hline & $24<$ Lage $<=36$ & $0.669^{\star \star *}$ & 4.8 & $0.678^{\star * *}$ & 4.9 \\
\hline & $36<$ Lage $<=48$ & $0.599^{\star * \star}$ & 4.8 & $0.605^{\star \star *}$ & 4.8 \\
\hline & $48<$ Lage $<=60$ & $0.602^{* * *}$ & 5.0 & $0.604^{* * *}$ & 5.0 \\
\hline & Fico & $-0.109^{* * *}$ & -45.5 & $-0.109^{* * *}$ & -45.4 \\
\hline & Ltv & $-0.071^{* * *}$ & -19.0 & $-0.070^{\star * *}$ & -18.8 \\
\hline & Cltv & $0.067^{* * *}$ & 16.5 & $0.067^{\star * \star}$ & 16.4 \\
\hline & Sehpi & $0.134^{\star \star *}$ & 9.4 & $0.133^{* * *}$ & 9.4 \\
\hline & Season & $0.017^{* \star *}$ & 11.3 & $0.017^{\star \star *}$ & 11.3 \\
\hline & Prepen & $0.189^{* * *}$ & 5.9 & $0.190^{* * *}$ & 6.0 \\
\hline & $\Delta \mathrm{l}$ & $-0.145^{\star \star \star}$ & -8.4 & $-0.146^{\star * *}$ & -8.5 \\
\hline & Urate & -0.008 & -0.9 & -0.007 & -0.9 \\
\hline & Cash-out & & & $-0.105^{\star \star *}$ & -2.5 \\
\hline & Constant & -0.043 & -0.2 & 0.016 & 0.1 \\
\hline \multicolumn{6}{|l|}{ Prepay } \\
\hline & Lage $<=6$ & $-0.722^{* \star *}$ & -10.1 & $-0.720^{* * *}$ & -10.1 \\
\hline & $6<$ Lage $<=8$ & 0.092 & 1.4 & 0.096 & 1.5 \\
\hline & $8<$ Lage $<=10$ & $0.291^{* * *}$ & 4.8 & $0.295^{\star * *}$ & 4.9 \\
\hline & $10<$ Lage $<=12$ & $0.458^{* \star *}$ & 7.9 & $0.463^{\star * *}$ & 8.0 \\
\hline & $12<$ Lage $<=18$ & $0.633^{* * *}$ & 12.6 & $0.637^{* * *}$ & 12.6 \\
\hline & $18<$ Lage $<=24$ & $0.529^{* * *}$ & 11.5 & $0.534^{* * *}$ & 11.6 \\
\hline & $24<$ Lage $<=36$ & $0.350 * * *$ & 8.9 & $0.355^{\star \star *}$ & 9.0 \\
\hline & $36<$ Lage $<=48$ & $0.275^{\star \star *}$ & 7.9 & $0.278^{* * *}$ & 8.0 \\
\hline & $48<$ Lage $<=60$ & $0.198^{* * *}$ & 5.9 & $0.199^{* * *}$ & 5.9 \\
\hline & Fico & $0.012^{* \star \star}$ & 13.5 & $0.012^{\star \star \star}$ & 13.5 \\
\hline & Ltv & $0.022^{\star \star \star}$ & 41.7 & $0.022^{* * *}$ & 41.8 \\
\hline & Cltv & $-0.032^{* * *}$ & -60.7 & $-0.032^{* * *}$ & -60.7 \\
\hline & Sehpi & $0.023^{* * *}$ & 4.5 & $0.023^{\star \star *}$ & 4.6 \\
\hline & Season & $-0.012^{* \star *}$ & -20.7 & $-0.012^{* * *}$ & -20.7 \\
\hline & Prepen & $-0.181^{* * *}$ & -16.2 & $-0.180^{\star \star *}$ & -16.1 \\
\hline & $\Delta \mathrm{I}$ & $-0.208^{* * *}$ & -32.1 & $-0.209^{* * *}$ & -32.2 \\
\hline & Urate & $0.025^{\star * *}$ & 9.6 & $0.025^{\star * *}$ & 9.5 \\
\hline & Cash-out & & & $-0.085^{\star \star *}$ & -4.9 \\
\hline & Constant & $-4.755^{\star * *}$ & -48.0 & $-4.705^{\star \star *}$ & -47.2 \\
\hline & $\begin{array}{l}\text { Log of } \\
\text { Likelihood }\end{array}$ & $-200,817.9$ & & $-200,802.3$ & \\
\hline
\end{tabular}

The hazard is estimated using multinomial logit in STATA. All variables are scaled as shown in tables 8 and 9. 
Table 10: The Likelihood of Defaulting and Prepaying: Cash-outs vs. Non-cash-outs

\begin{tabular}{|c|c|c|c|c|c|c|}
\hline & \multicolumn{2}{|c|}{ Baseline } & \multicolumn{2}{|c|}{ Cash-out } & \multicolumn{2}{|c|}{ No Cash-out } \\
\hline & Coefficent & z-stat & Coefficent & z-stat & Coefficent & z-stat \\
\hline \multicolumn{7}{|l|}{ Panel A: Default } \\
\hline constant & -0.193 & -0.7 & & & & \\
\hline Lage $<=6$ & $-0.905^{\star \star *}$ & -4.1 & & & & \\
\hline $6<$ Lage $<=8$ & 0.169 & 0.9 & & & & \\
\hline $8<$ Lage $<=10$ & $0.424^{\star \star}$ & 2.2 & & & & \\
\hline $10<$ Lage $<=12$ & $0.589^{* * *}$ & 3.2 & & & & \\
\hline $12<$ Lage $<=18$ & $0.587^{* * *}$ & 3.5 & & & & \\
\hline $18<$ Lage $<=24$ & $0.656^{* * *}$ & 4.2 & & & & \\
\hline $24<$ Lage $<=36$ & $0.673^{* * *}$ & 4.8 & & & & \\
\hline $36<$ Lage $<=48$ & $0.599^{* * *}$ & 4.8 & & & & \\
\hline $48<$ Lage $<=60$ & $0.602^{* * *}$ & 5.0 & & & & \\
\hline Fico & & & $-0.109^{\star * *}$ & -42.7 & $-0.106^{* * *}$ & -27.3 \\
\hline Ltv & & & $-0.076^{\star * *}$ & -18.6 & $-0.032^{* * *}$ & -3.8 \\
\hline Cltv & & & $0.072^{\star \star \star}$ & 16.1 & $0.037^{\star * *}$ & 4.4 \\
\hline Sehpi & & & $0.149^{* * *}$ & 10.4 & $0.063^{* * *}$ & 2.9 \\
\hline Season & & & $0.017^{* * *}$ & 10.6 & $0.014^{\star * *}$ & 3.8 \\
\hline Prepen & & & $0.228^{* * *}$ & 6.5 & -0.006 & -0.1 \\
\hline$\Delta \mathrm{l}$ & & & $-0.154^{* * *}$ & -8.3 & $-0.081^{*}$ & -1.9 \\
\hline Urate & & & -0.006 & -0.7 & -0.024 & -1.0 \\
\hline \multicolumn{7}{|l|}{ Panel B: Prepay } \\
\hline constant & $-4.761^{\star * \star}$ & -47.8 & & & & \\
\hline Lage $<=6$ & $-0.727^{\star \star *}$ & -10.2 & & & & \\
\hline $6<$ Lage $<=8$ & 0.093 & 1.5 & & & & \\
\hline $8<$ Lage $<=10$ & $0.294^{\star * \star}$ & 4.8 & & & & \\
\hline $10<$ Lage $<=12$ & $0.463^{* * *}$ & 8.0 & & & & \\
\hline $12<$ Lage $<=18$ & $0.639^{\star * *}$ & 12.7 & & & & \\
\hline $18<$ Lage $<=24$ & $0.535^{\star * *}$ & 11.7 & & & & \\
\hline $24<$ Lage $<=36$ & $0.357^{* * *}$ & 9.0 & & & & \\
\hline $36<$ Lage $<=48$ & $0.281^{* * *}$ & 8.0 & & & & \\
\hline $48<$ Lage $<=60$ & $0.202^{\star * \star}$ & 6.0 & & & & \\
\hline Fico & & & $0.011^{* * *}$ & 11.4 & $0.018^{* * *}$ & 12.4 \\
\hline Ltv & & & $0.022^{\star \star \star}$ & 40.7 & $0.026^{\star \star *}$ & 11.1 \\
\hline Cltv & & & $-0.032^{\star * *}$ & -59.3 & $-0.035^{\star * *}$ & -15.9 \\
\hline Sehpi & & & $0.025^{\star \star *}$ & 4.9 & 0.007 & 0.8 \\
\hline Season & & & $-0.012^{* * *}$ & -19.5 & $-0.012^{* * *}$ & -7.1 \\
\hline Prepen & & & $-0.154^{\star * *}$ & -13.0 & $-0.372^{\star \star *}$ & -11.7 \\
\hline$\Delta \mathrm{l}$ & & & $-0.210^{\star \star *}$ & -30.7 & $-0.191^{* * *}$ & -9.5 \\
\hline Urate & & & $0.028^{* * *}$ & 10.1 & -0.003 & -0.3 \\
\hline Log of Likelihood & $-200,726.7$ & & & & & \\
\hline
\end{tabular}

The hazard is estimated using multinomial logit in STATA. All variables are scaled as shown in tables 8 and 9. 
Table 11: Marginal Effects on Default/Prepayment Probabilities: Cash-out vs. Noncash-outs

\begin{tabular}{l|lrrrr}
\hline & & I & II & \multicolumn{2}{c}{ III } \\
\hline Default & & & & Cash-out & No Cash-out \\
\hline & Fico & -0.11 & -0.11 & -0.11 & -0.11 \\
& Ltv & -0.07 & -0.07 & -0.08 & -0.03 \\
& Cltv & 0.07 & 0.07 & 0.07 & 0.04 \\
& Sehpi & 0.13 & 0.13 & 0.15 & 0.06 \\
& Season & 0.02 & 0.02 & 0.02 & 0.01 \\
& Prepen & 0.19 & 0.19 & 0.23 & 0.00 \\
& Il & -0.14 & -0.14 & -0.15 & -0.08 \\
& Urate & -0.01 & -0.01 & -0.01 & -0.02 \\
& Cash-out & & -0.11 & & \\
\hline Prepay & & & & & \\
\hline & Fico & 0.01 & 0.01 & 0.01 & 0.02 \\
& Ltv & 0.02 & 0.02 & 0.02 & 0.03 \\
& Cltv & -0.03 & -0.03 & -0.03 & -0.03 \\
& Sehpi & 0.02 & 0.02 & 0.02 & 0.01 \\
& Season & -0.01 & -0.01 & -0.01 & -0.01 \\
& Prepen & -0.18 & -0.18 & -0.15 & -0.37 \\
& $\Delta$ l & -0.20 & -0.20 & -0.20 & -0.19 \\
& Urate & 0.02 & 0.02 & 0.03 & 0.00 \\
& Cash-out & & -0.09 & & \\
\hline
\end{tabular}

The proportional marginal effect is the percent change (not percentage point change) in the probability of the hazard (default or prepay) caused by a one unit increase in the variable of interest. Loan age is set to the category indicated by the mean age in the sample $(18<$ Lage $<=24)$ and all other variables are evaluated at their means. In addition, reflecting the use of a cash-out or a no cash-out loan, in specification III when the cash-out marginal effects are calculated the cash-out dummy and all it's interaction variables are set to 1 and when the no cash-out marginal effects are calculated the cash-out dummy and all it's interaction variables are set to 0 . 
Table 12: Seasoning and Marginal Effects on Default/Prepayment Probabilities

\begin{tabular}{|c|c|c|c|c|c|c|}
\hline \multirow{3}{*}{ default } & \multirow{2}{*}{\multicolumn{3}{|c|}{$\begin{array}{c}\text { Cash-out } \\
\text { Seasoning Length in Months }\end{array}$}} & \multirow{2}{*}{\multicolumn{3}{|c|}{$\begin{array}{c}\text { No Cash-out } \\
\text { Seasoning Length in Months }\end{array}$}} \\
\hline & & & & & & \\
\hline & $\mathrm{S}<=3$ & $3<S<=6$ & $S>6$ & $S_{<}=3$ & $3<S<=6$ & $S>6$ \\
\hline Fico & -0.11 & -0.13 & -0.10 & -0.11 & -0.11 & -0.09 \\
\hline Ltv & -0.09 & -0.13 & -0.06 & -0.05 & -0.02 & -0.03 \\
\hline Cltv & 0.09 & 0.13 & 0.06 & 0.06 & 0.02 & 0.03 \\
\hline Sehpi & 0.18 & 0.25 & 0.10 & 0.09 & 0.17 & 0.05 \\
\hline Season & -0.13 & 0.15 & 0.02 & 0.01 & -0.10 & 0.02 \\
\hline Prepen & 0.15 & 0.24 & 0.31 & -0.08 & 0.16 & 0.09 \\
\hline$\Delta \mathrm{l}$ & 0.01 & -0.30 & -0.32 & -0.04 & -0.13 & -0.12 \\
\hline Urate & 0.00 & -0.03 & 0.00 & -0.05 & -0.03 & 0.02 \\
\hline \multicolumn{7}{|l|}{ prepay } \\
\hline Fico & 0.01 & 0.02 & 0.01 & 0.02 & 0.03 & 0.01 \\
\hline Ltv & 0.02 & 0.02 & 0.03 & 0.03 & 0.02 & 0.02 \\
\hline Cltv & -0.03 & -0.03 & -0.03 & -0.04 & -0.03 & -0.03 \\
\hline Sehpi & 0.05 & 0.05 & 0.01 & 0.03 & 0.04 & 0.00 \\
\hline Season & 0.03 & 0.03 & -0.01 & 0.05 & -0.10 & -0.01 \\
\hline Prepen & -0.21 & -0.21 & 0.04 & -0.35 & -0.37 & -0.10 \\
\hline$\Delta \mathrm{l}$ & -0.24 & -0.24 & -0.13 & -0.21 & -0.29 & -0.07 \\
\hline Urate & -0.01 & 0.02 & 0.00 & -0.01 & 0.02 & 0.00 \\
\hline
\end{tabular}

$\mathrm{S}$ indicates the number of months that the loans used to estimate the reported coefficients were seasoned before being observed in the data set and likely securitized. The proportional marginal effect is the percent change (not percentage point change) in the probability of the hazard (default or prepay) caused by a one unit increase in the variable of interest. Using specification III loan age is set to the category indicated by the mean age in the sample $(18<\operatorname{Lage}<=24)$ and all other variables are evaluated at their means. 
Figure 1:

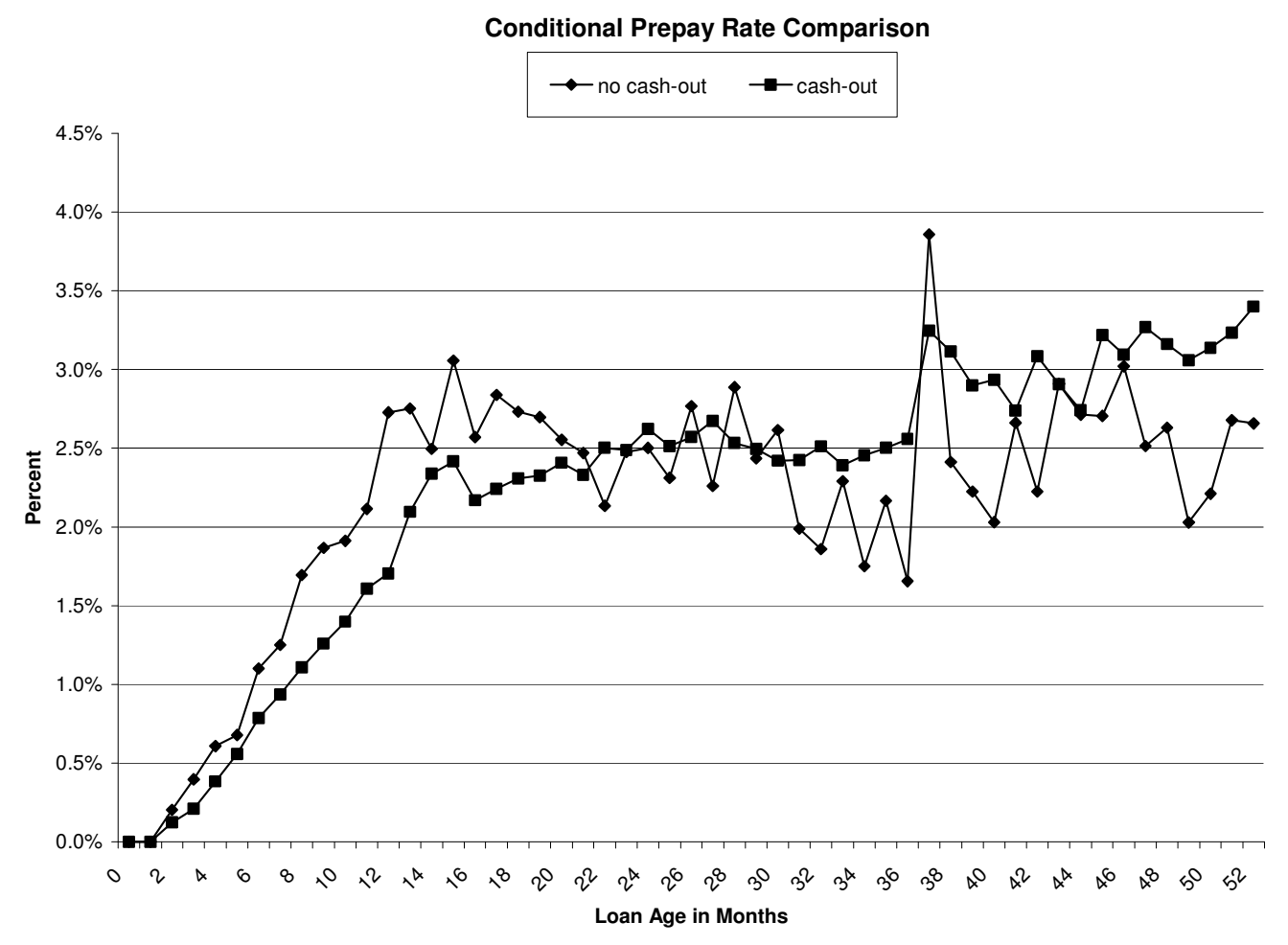

Figure 2:

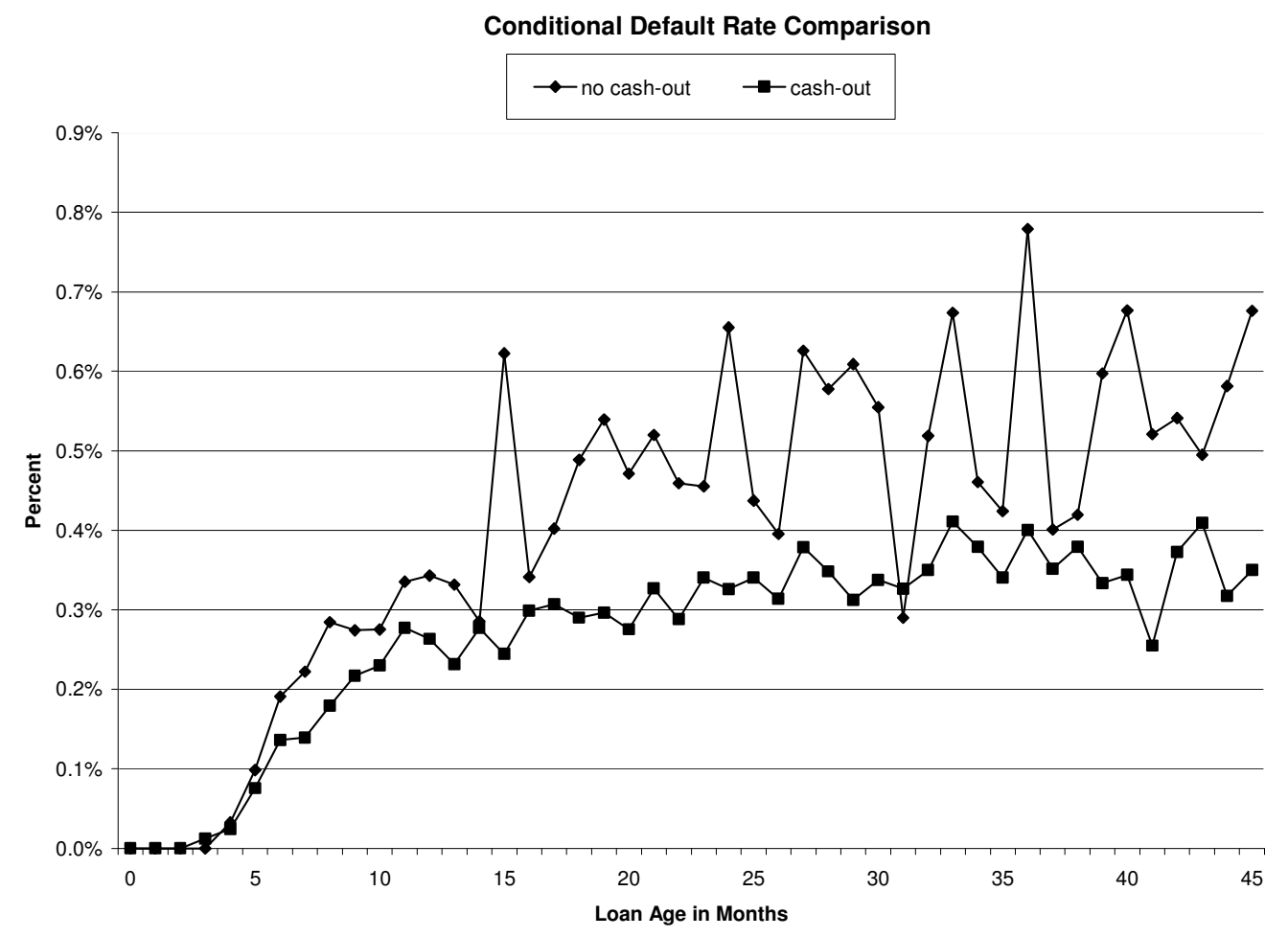

